\title{
Reef bioconstructors of the Rocas Atoll, Equatorial South Atlantic
}

\author{
Marcelo de Oliveira Soares ${ }^{1 *}$ \\ Carlos Augusto Oliveira de Meirelles $^{2}$ \\ Valesca Brasil Lemos ${ }^{3}$ \\ ${ }^{1}$ Instituto de Ciências do Mar - Labomar, Universidade Federal do Ceará \\ Av. da Abolição, 3207, CEP 60165-081, Fortaleza - CE, Brasil \\ ${ }^{2}$ Departamento de Biologia, Centro de Ciências, Universidade Federal do Ceará \\ Av. Mister Hull, s/n, CEP 60455-760, Fortaleza - CE, Brasil \\ ${ }^{3}$ Departamento de Paleontologia e Estratigrafia, Instituto de Geociências \\ Universidade Federal do Rio Grande do Sul \\ Av. Bento Gonçalves, 9500, CEP 91509-900, Porto Alegre-RS, Brasil \\ *Autor para correspondência \\ bio_marcelo@yahoo.com.br
}

Submetido em 30/11/2010 Aceito para publicação 02/04/2011

\section{Resumo}

Bioconstrutores recifais do Atol das Rocas, Atlântico Sul Equatorial. Este estudo apresenta uma análise dos bioconstrutores recifais do Atol das Rocas, Nordeste do Brasil, amostrados em janeiro e fevereiro de 2008. Os resultados demonstraram a presença de uma comunidade constituída principalmente por algas calcárias (Porolithon pachydermum, Sporolithon sp., Lithoporella sp., Lithophyllum sp.), corais (Siderastrea stellata, Favia gravida), moluscos vermetídeos (Dendropoma irregulare, Petaloconchus varians) e foraminíferos (Homotrema rubrum) na formação do recife. Este levantamento taxonômico demonstra a importância de diferentes espécies durante o processo de crescimento carbonático do único atol do Atlântico Sul Equatorial.

Palavras-chave: Algas calcárias, Corais escleractíneos, Foraminíferos, Moluscos vermetídeos, Recifes

\section{Abstract}

This study presents an analysis of reef bioconstructors at the Rocas Atoll, Brazil's Northeast, sampled in January and February 2008. The results showed the presence of a community made up mainly of calcareous algae (Porolithon pachydermum, Sporolithon sp., Lithoporella sp., Lithophyllum sp.), corals (Siderastrea stellata, Favia gravida), vermetid mollusks (Dendropoma irregulare, Petaloconchus varians), and foraminifers (Homotrema rubrum) in the reef formation. This taxonomic survey shows the importance of a different species during the carbonate growth process of the only atoll in the Equatorial South Atlantic.

Key words: Calcareous algae, Foraminifers, Reefs, Scleractinian corals, Vermetid mollusks 


\section{Introduction}

Bioconstruction can be defined as production of sedimentary deposits, accretions or accumulations by organic processes and it often involves active and passive biological influences. In bioconstruction there is formation of films, incrustation, topographic elevations or reefs from materials produced internally (e.g., deposition of biogenic carbonate), removed from other materials (e.g., organic cementation) or developing a combination of both methods. Some bioconstructions are short-term phenomena, due to nonlinear growth cycles or decay standards, while other bioconstructions suffer secondary diagenesis and lithification (PERRIN, 1992; GHERARDI; BOSENCE, 2001; NAYLOR et al., 2002; GISCHLER; HUDSON, 2004).

There are basically three ways of bioconstructive processes (NAYLOR, 2005): 1) when the organisms themselves produce biomineralized material, such as secretion from carbonate skeletons by vermetid mollusks and in bioherms of coralline algae; 2) when the organisms add material by chemical fixation of particulate matter, as in the case of sabellarid polychaetes that build tubes with beach sand through the production of an organic cement; 3) when inorganic cementation combines organic matter like fluvial tufa.

A biogenic reef is, according to Lowenstam (1950), "[...] the product of constructive and aggregating/ cementing activity of biotic constituents that, due to their potential to resist the waves, erect topographic structures resistant to them." According to Cloud (1959), any reef complex, at any time, is the result of its chain of nutrients, the breakdown product, and its geological history, adds Stoddart (1969). This construction is therefore the result of organic activity in response to environmental factors (hydrophysical and hydrochemical) that are incorporated to the geological record (GISCHLER; HUDSON, 2004).

The Rocas Atoll is located at the top of a chain of submarine mountains in the South Atlantic Ocean, whose base is located at a depth of $4,000 \mathrm{~m}$ in the ocean bed, at $3^{\circ} 51^{\prime} \mathrm{S}$ Latitude and $33^{\circ} 49^{\prime} \mathrm{W}$ Longitude, $266 \mathrm{~km}$ from the city of Natal and $150 \mathrm{~km}$ west of the
Fernando de Noronha archipelago, in the Brazilian Northeast (ANDRADE, 1959; KIKUCHI; LEÃO, 1997). Since the end of the $20^{\text {th }}$ century, with the effective implementation of research activities at REBIO (Biological Reserve), the Atoll has been studied more frequently, with several scientific studies focusing on geology, corals, foraminifers, and calcareous algae (MACHADO; SOUZA, 1994; ROSSI et al., 1996; KIKUCHI; LEÃO, 1997; MAIDA; FERREIRA, 1997; GHERARDI; BOSENCE, 1999; 2001; AMARAL et al., 2002; SOARES et al., 2009; 2010; PEREIRA et al., 2010).

Despite these studies, a series of geobiological aspects (like the bioconstructors species) of the Rocas Atoll remain poorly studied, despite its importance and unique characteristics as the only atoll of the Equatorial South Atlantic (KIKUCHI; LEÃO, 1997; SOARES et al., 2009). This study is therefore aimed at contributing towards the taxonomic survey of the bioconstructors species in the Rocas Atoll (NE Brazil).

\section{Material and Methods}

\section{Study area}

The atoll has a volcanic origin and carbonate formation in the reef, with a slightly ellipsoidal structure, almost circular in its larger axis (E-W), which is about $3.7 \mathrm{~km}$ length, and its smaller axis $(\mathrm{N}-\mathrm{S})$ has $2.5 \mathrm{~km}$ (KIKUCHI, 2002). The study by Kikuchi and Leão (1997) describes the Atoll as a reef ring, set up on a submarine mount of the guyot type. This ring is made up, from the morphological point of view, of layered terraces that dam the waters during the low tides. These waters form a system of pools (with the maximum depth of $5 \mathrm{~m}$ ), leaving only two islands visible. In the northeastern portion of the ring, we notice an area that is always submerged and it gives origin to the reef lagoon. The ocean waters have access to the reef interior through the canals (reef pass) (Figure 1). 


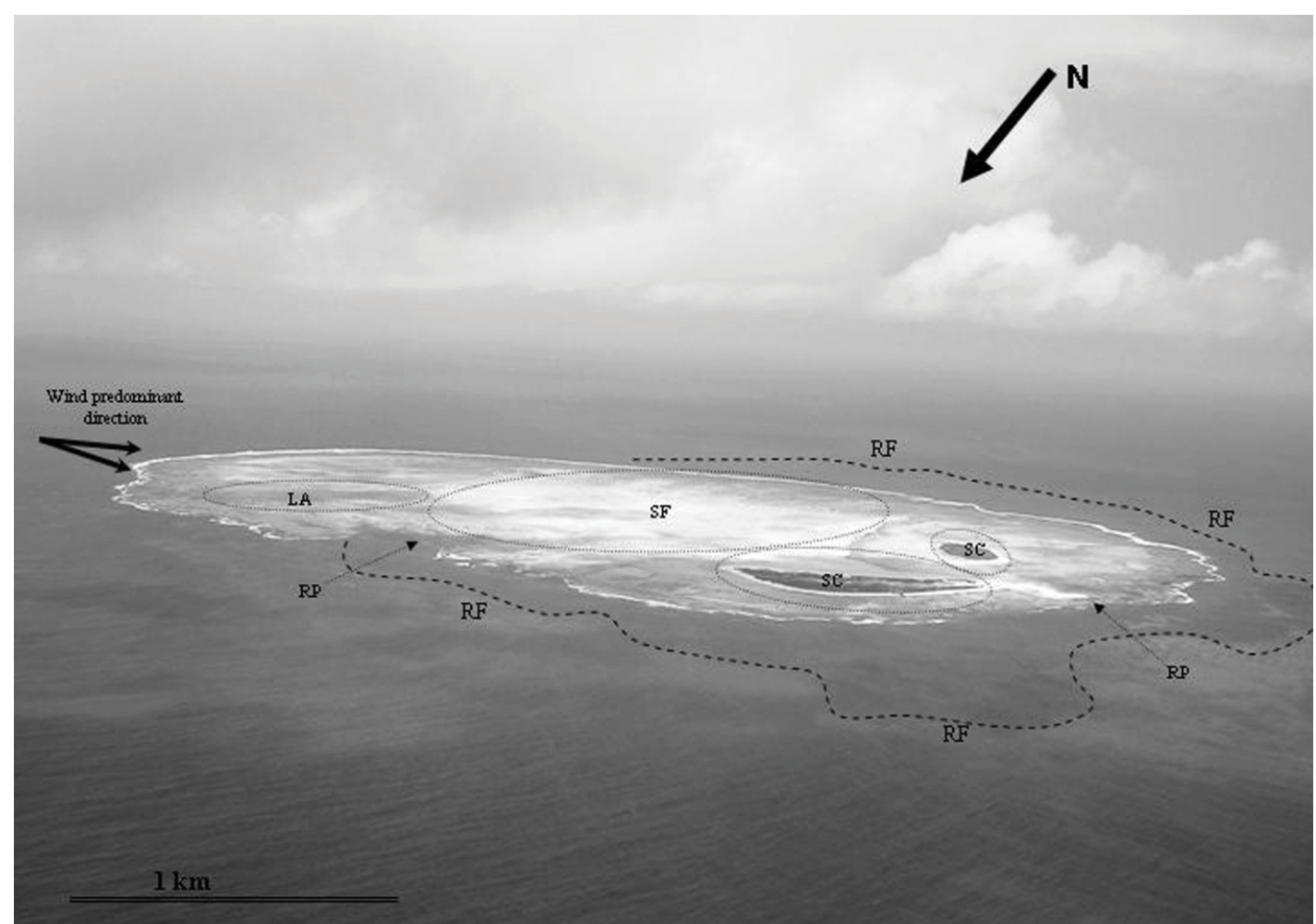

FIGURE 1: The Rocas Atoll (Equatorial South Atlantic) showing the studied zones in windward and leeward sides: LA $=$ Lagoon; $\mathrm{SF}=$ Sand flat; $\mathrm{SC}=$ Sand cays; $\mathrm{RP}=$ Reef Pass; $\mathrm{RF}=$ Reef front. Image obtained from field activities during the low tide.

\section{Field and laboratory}

The collections were made at REBIO (Biological Reserve), at the Rocas Atoll, from January 30 to February 28,2008 . The Atoll was accessed by lifebuoy through the canal located in the NW part of the reef during the high tide.

The approach to the general aspect of the Rocas Atoll required different stages such as interpretation of map images from the area and visualization both of in situ characteristics of the bioconstructors and the occurrence zones in the reef. The observation was performed during walks at the top of the reef, which is exposed in the low tides, and during dives (free-diving and SCUBA), in the submersed parts. The data obtained in these description points were: a) the main occurrence zones of the atoll bioconstructors; and b) the bioconstructor organisms. These data were completed with detailed photographic documentation and samplings of the main constructors of the reef structure.
The geological samples were obtained from surface and depth collections through SCUBA diving in various geoenvironmental compartments of the Rocas Atoll. The samples were described macroscopically and microscopically, photographed and parts of them were selected for taxonomic description of the main bioconstructors.

Organisms not identified in the field were kept in $4 \%$ formaldehyde saline solution for later identification. The bioconstructors were identified through the comparison with samples from other reefs in Brazil's Northeast which belong to the Instituto de Ciências do Mar and the Laboratório de Invertebrados Marinhos, both from Universidade Federal do Ceará - UFC; the Instituto de Geociências of the Universidade Federal da Bahia - UFBA and the Instituto de Geociências of the Universidade Federal do Rio Grande do Sul - UFRGS. The works by Smith (1971), Araújo (1984), Leão (1986), Nolasco (1987) and Kikuchi (2002) were also used. 
The studies by Wray (1977), Penrose and Woelkerling (1988), Littler and Littler (2000), and Horta (2002) were consulted for the identification of the genus and species of calcareous algae.

\section{Results and Discussion}

The reef geology of the Rocas Atoll is a carbonate deposit that resulted from the bioconstructor activity of benthonic organisms in response to environmental factors like availability of light, sea hydrodynamics, subsidence, and eustatic variations. Paleontologically, the taphocoenosis is dominantly made up of calcareous algae, vermetid mollusks (Figure 2B), foraminifers and only secondarily by corals (Figure 2D). This fact is important (KIKUCHI, 2002) because it is usually accepted that coralline algae lack potential to erect or to be primary constructors of reefs in the neogene (Figure 2A).

From the paleobiological point of view, coralline reefs, like the Rocas Atoll, are formations created by the action of several types of organisms like corals, calcareous algae, vermetid mollusks, foraminifers, among others (Figure 2C). Kikuchi and Leão (1997) and Kikuchi (2002) observed that the large volume of coralline algae in the thick reef sequences suggest that there are circumstances when coralline algae and associated encrusting organisms behave not only as binders but, also, as reef builders. In the studied area, coralline algae are the dominant reef-builders between 0 and $15 \mathrm{~m}$ depth (Figure 2E).

In reefs of the Caribbean in the Atlantic Ocean, the corals correspond to the greater volumetric part of depositions of the holocenic section, however, one notices a great contribution from: coralline algae, Halimeda sp., fragments of mollusks and incrusting foraminifers (GISCHLER; HUDSON, 2004). Calcareous algae are common in the description of carbonate sedimentary facies and in the bioconstruction of reef environments. Modern reefs have a thickness of over $10 \mathrm{~m}$ and many are built primarily by calcareous algae (OTTMAN, 1963; KIKUCHI; LEÃO, 1997; KIKUCHI, 2002; SOARES et al., 2009).
The corals that compose the reefs described in this work differ from the Caribbean reefs, in which the latter are largely composed of Acropora, Montastraea, Diploria and Porites. They also differ from the southern Abrolhos reef complex, which is mainly built by Mussismilia braziliensis Verrill, 1868 (LEÃO et al., 1988). Two dominant reef-building coral species were identified: Siderastrea stellata Verrill, 1868 (Figure 3F) and Favia gravida Verrill, 1868 (KIKUCHI, 2002).

Encrusting foraminiferans (homotrematids and acervulinids) are concentrated in the reef-ridge and the inner reef-flat, but seem not to be significantly affected by sedimentation, or maybe it is not high enough.

\section{Systematic paleontology \\ Siderastrea stellata Verrill, 1868 (Figure 3F)}

Description: Coral with a compact colony, more or less spheric in outline. Live colonies which live in very shallow waters have a reddish color, are usually small (diameter from 5 to $10 \mathrm{~mm}$ ), have calyxes with diameter from 2 to $3 \mathrm{~mm}$, roundish, deep and the fourth cycle of septa is incomplete.

Remarks: The species is common in the Brazilian coast and in the oceanic islands in the Brazilian Northeast and in part of the Southeast. S. stellata is an endemic coral, widely distributed on the Brazilian coasts (NEVES; SILVEIRA, 2003). It is very similar to Caribbean species, but with bigger calyxes, septa more delicate and wider interseptal spaces. This coral displays a morphological variation that distinguishes colonies of shallow waters from those of deep waters (deeper than $5 \mathrm{~m}$ ) (LABOREL, 1969a and 1969b; LEÃO, 1986; PIRES et al., 1992; HETZEL; CASTRO, 1994; PIRES, 1995 and 1997; ECHEVERRÍA; PIRES, 1997; KIKUCHI; LEÃO, 1997; KIKUCHI, 2002; SANTOS et al., 2004; AMARAL et al., 2007; NEVES et al., 2010). 

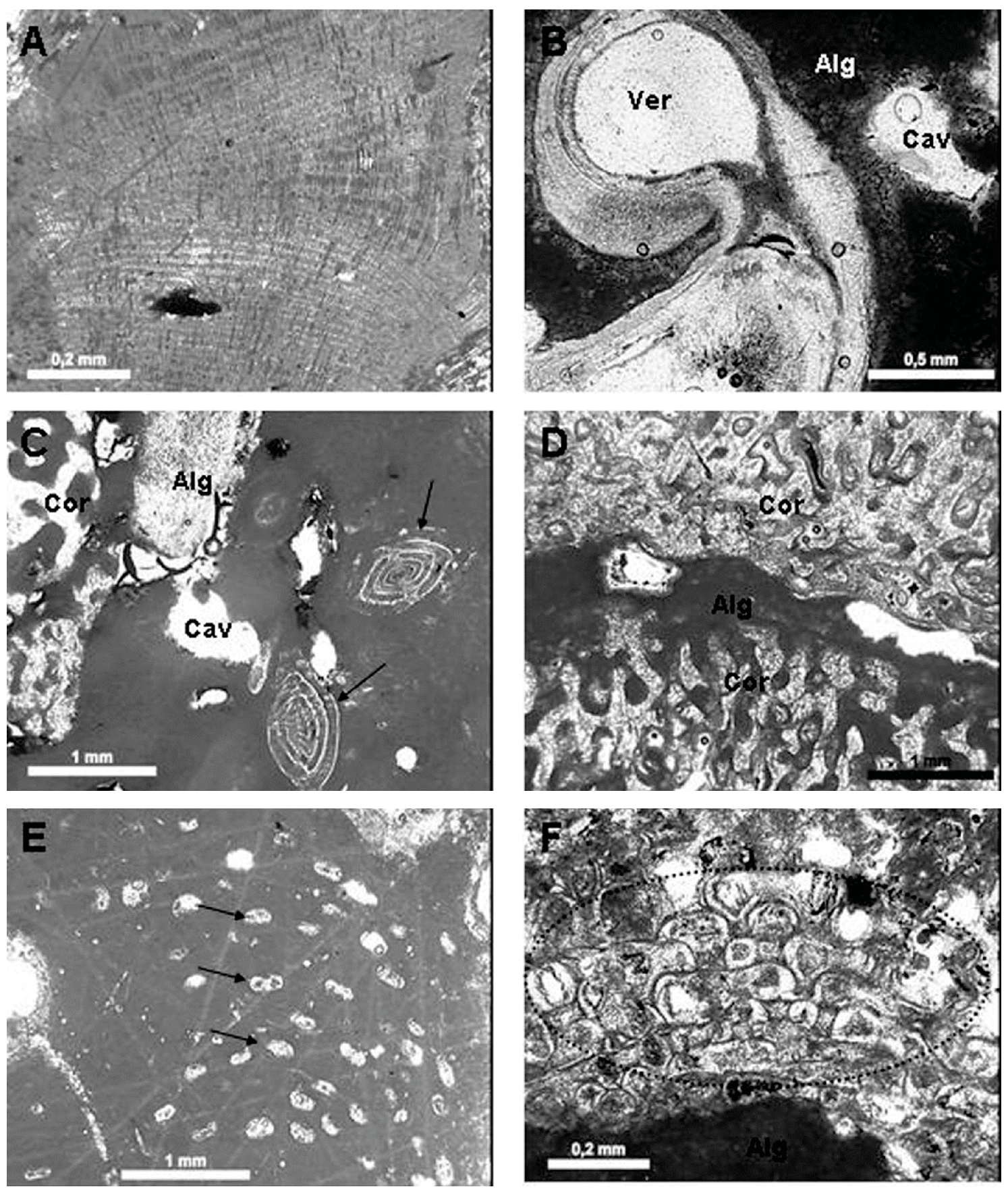

FIGURE 2: (A) Red encrusting coralline algae biolithite partially micritized. The magnesium-calcite micrite is responsible for the extensive micritization of the stalks of these algae; (B) Vermetid gastropod shell with non-filled in internal porosity (Ver). Presence of Porolithon pachydermum (Foslie, 1909) algae acting as a competitor for the space (Alg) and cavity/ boring (Cav); (C) Polytypic subfossiliferous assembly formed by scleractinian corals (Co), bentonic foraminifers (arrows), red coralline algae (Alg) and cavity/boring by bioerosion (Cav); (D) Evidence of competition for space by coralline algae and scleractinian corals in the bioconstructive process; (E) Detail of the red algae biolithite with sporangium (reproductive structures) indicated by arrows; (F) Bioconstruction (ellipse) of vermetid gastropod shells (Dendropoma irregulare Orbigny, 1842) on top of bioconstructing red algae (Alg). Such gastropods are one of the main bioconstructors of the Rocas Atoll reef and indicators of the variations of the sea level due to being in intertidal or immediately subtidal zones. 

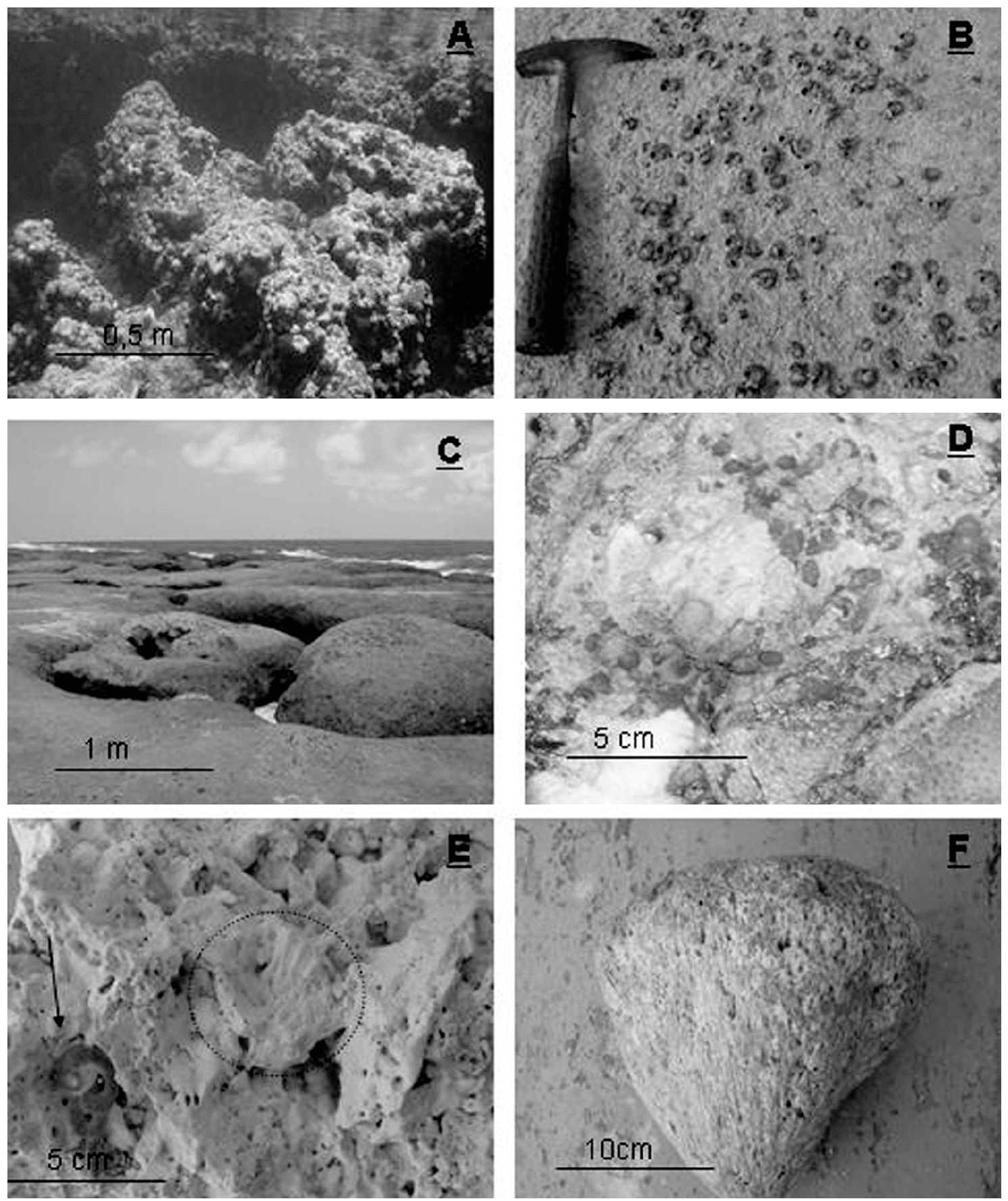

FIGURE 3: Bioconstructor taphocoenosis of the Rocas Atoll: (A) Calcareous algae carbonate bioconstruction (Sporolithon sp., Lithophyllum, Lithoporella sp.) in pool on windward side; (B) Bioaccumulation with vermetid gastropods in the atoll. Bindstone Facies Algal-Mollusca; (C) Reef ring (windward) mainly bioconstructed by calcareous algae Porolithon pachydermum Foslie, 1909. This characteristic is differentiated in relation to the other atolls in the Caribbean and Indian-Pacific regions; (D) Macroscopic aspect of several bioaccumulations (globes) of foraminifera Homotrema rubrum (Lamarck, 1816) in the atoll; (E) Detail of a sample of the paleoreef from the atoll showing the main fossilized bioconstructors. Vermetid gastropod bioconstructor Petaloconchus varians (arrow) is indicator of intertidal or immediate sub-tidal environment, Central part with scleractinia coral (circle). Main framework: Calcareous algae. Carbonate facies of Alga-Coral-Mollusca Framestone; (F) Scleractinia coral Siderastrea stellata from the quaternary paleoreef of the Rocas Atoll, Western South Atlantic. 
Favia gravida Verrill, 1868

Description: This species has solid, spherical and hemispherical colonies, bearing a light brown or yellowish color. Calyxes are unequal, roundish, oval or long, often deformed. Due to the great variation on shape of the calyxes, Laborel (1969a) describes three different shapes, types 1, 2 and 3, each one of them with three morphological variations, named $\mathrm{A}, \mathrm{B}$ and $\mathrm{C}$, which variate according to the depth where the polyps live.

Remarks: This species is very resistant to environmental variations, particularly regarding the temperature, salinity and water turbidity. Together with Siderastrea stellata, they are the most common corals in shallow pool tides on the emersed top of the coastal reefs and even on non-reefy substrata along the beaches. It is an endemic species of the Brazilian fauna in neogene reefs (LABOREL, 1969a and 1969b; LEÃO, 1986; PIRES et al., 1992; HETZEL; CASTRO, 1994; ECHEVERRÍA; PIRES, 1997; KIKUCHI; LEÃO, 1997; AMARAL; RAMOS, 2007).

Porolithon pachydermum (Foslie) Foslie, 1909 (Figures 2E and 3C)

Description: Plants are epigenous with pseudoparenchymatous thalli, applanate crustose to protuberant thalli. Crustose portion of the plant dorsiventral, monomerous composed of a noncoaxial core and a more peripheral dorsal region where filaments curve upwards from the core towards the thallus surface. It has typical shapes of crest and slots observed in the field. Vilas-Boas et al. (2005) comment on cellular characteristics that are diagnoses of the species as singlepore conceptacles, trichocysts in horizontal groups, perithalial cells connected by fusion and hypothalial cells arranged horizontally parallel to the substrate.

Remarks: The species is common in the Caribbean, mainly in the reefs of the Bahamas and Antilles. In the Northeastern region of Brazil, it is very common in the reefs of Abrolhos and in the Rocas Atoll (GHERARDI; BOSENCE, 1999). It has crusted habit with frequency bored by polychaetes and associated with the Homotrema rubrum foraminifer. It is found in all the reef habitats described. Color varies from light brown to dark purple, plane to protuberant surface, smooth texture and strongly attached margin. Macintyre (1997) showed that the most extensive crustose coralline algal pavements studied to date are those associated with Pacific reefs. These pavements consist mainly of Porolithon spp.

\section{Lithoporella sp. (Figure 3A)}

Description: Plants are epigenous with pseudoparenchymatous thalli, thin applanate crustose thalli, dorsiventral and monomerous. Primigenous filaments form a unistratose layer composed of palisade cells. Conceptacles were not found in the inspected specimens.

Remarks: Kikuchi and Leão (1997) comment that Lithoporella is one of the main calcareous algae in reefs of Abrolhos, Brazil's Northeast. Gherardi and Bosence (1999) discuss that there are probably two species per genus residing in the Atoll. Woelkerling (1988) presented a combination of diagnostic features that differentiate Lithoporella from other genera of Mastophoroidae as follows: a) nonendophytic thallus lacking haustoria; b) primigenous filaments composed of palisade cells; c) lack of coaxial core of filaments.

\section{Lithophyllum sp. (Figure 3A)}

Description: Plants epigenous, pseudoparenchymatous thalli, varying in form from applanate to columnar thalli. Columnar plants are monomerous with a central core of coaxial or noncoaxial filaments and a peripheral region where distal portions of core filaments or their derivates curve outwards towards the thallus surface.

Remarks: Woelkerling and Campbell (1992) found dimerous thalli in crustose portions of Lithophyllum from southern Australian species. Gherardi and Bosence (1999) did not found them in the specimens from the Rocas Atoll. The genus Lithophyllum is restricted to the lower intertidal and uppermost subtidal in the study area.

\section{Sporolithon sp. (Figure 3A)}

Description: Plants epigenous, pseudoparenchymatous thalli, with applanate crustose thalli sometimes forming spherical thalli. Monomerous in 
crustose portions. Core of noncoaxial filaments where distal portions curve outwards towards thallus surface. Lacks palisade cells.

Remarks: It belongs to the Melobesioideae subfamily. Kikuchi and Leão (1997) comment that Sporolithon sp. is one of the main calcareous algae of the reefs of Abrolhos, Brazil's Northeast. Woelkerling (1988) gives a detailed account on the historical controversy that surrounded the application of the names Archaeolithothamnium Rothpletz (1891) and Archaeolithothamnium Rothpletz ex Foslie (1898) as opposed to the name Sporolithon.

\section{Homotrema rubrum (Lamarck, 1816) (Figure 3D)}

Description: Homotrema is a calcareous encrusting foraminifera genus, with a large test (usually more than 8 $\mathrm{mm}$ diameter), with varied shape (globular, hemispheric) and presenting different types of encrustation: irregular, conic, truncated. The first chamber is branched and/ or spiraled, and the last ones are distributed in layers. Irregular openings between lateral walls occur when new chambers are added. These unilocular microfossils have, when alive, a common reddish color, caused by the pigment decomposition of hosted endossimbionts (LOEBLICH; TAPPAN, 1964 and 1988), but become light-pink to whitish after death (EMILIANI, 1951).

Remarks: The high wave energy on this reef environment is responsible for the fragmentation of the reef structure, which is composed by corals, coralline algae and several encrusting organisms, e.g. Homotrema and vermetids (Dendropoma irregulare) in the Rocas Atoll (GHERARDI; BOSENCE, 2001) and in Bahia reefs (NOLASCO, 1987).

\section{Dendropoma irregulare (Orbigny, 1842) (Figures $2 \mathrm{~F}$ and $3 \mathrm{~B}$ )}

Description: Shell worm-tube with 6 to $8 \mathrm{~mm}$ diameter. Exterior grayish, brown inside. Strongly coiled. Sculptured with a longitudinal scaled rib. Colonial forms usually; compressed masses attached to rocks, corals and other shells. Dendropoma nebulosa (Dillwyn, 1817) is the same.

Remarks: Living in colonies forming vermetid reefs in the Rocas Atoll (Brazil's Northeast). Other occurrences in Para to South Bahia; the Rocas Atoll, Fernando de Noronha, Abrolhos reefs and Trindade Islands (RIOS, 1994; SOARES et al., 2010).

Petaloconchus varians (Orbigny, 1841) (Figure 3E)

Description: Vermiform mollusk forming compact colonies $(100 \mathrm{~mm}$ length and $2 \mathrm{~mm}$ diameter). Very variable growing in all directions. Color dark brown, reddish brown to orange. Sculptured with longitudinal ribs sometimes reticulate. Operculum concave, translucent and multispiral. Aperture circular.

Remarks: The species occur in Bermuda, Florida, West Indies and Brazil along the coast and oceanic islands (RIOS, 1994; SOARES et al., 2010).

The reef taphocoenosis of the only South Atlantic Atoll was studied revealing the presence of calcareous algae (Porolithon pachydermum, Sporolithon sp., Lithoporella sp., Lithophyllum sp.), corals (Siderastrea stellata and Favia gravida), vermetids (Dendropoma irregulare and Petaloconchus varians) and foraminifers (Homotrema rubrum) in the bioconstruction of this neogene ocean reef. Later taxonomic studies may identify the calcareous algae species of the genus proposed here. A paleoecological model should be elaborated to explain the predominance of these organisms in the reef construction, along the Holocene, different from the coral reefs around the world.

\section{Acknowledgments}

The first author thanks the CNPq (National Scientific Research and Development Board) for granting his Doctorate scholarship. Petrobras and Fundação SOS Mata Atlântica for financing the research in the field works. ICMBIO for granting the research license and supporting the field activities (mainly the coordinator of Reserva Biológica Maurizélia Brito).

\section{References}

AMARAL, F. M. D.; BROADHURST, M.; CAIRNS, S. D.; SCHLENZ, E. Skeletal morphometry of Millepora species occuring in Brazil, including a previously new species. Proceedings of the 
Biological Society of Washington, Washington, v. 115, n. 3, p. 681-695, 2002.

AMARAL, F. M. D.; HUDSON, M. M.; STEINER, A. Q.; RAMOS, C. A. C. New findings on corals and calcified hydroids of the Manuel Luiz Marine State Park (State of Maranhão, Northeast Brazil). Biota Neotropica, São Paulo, v. 7, p. 1-9, 2007.

AMARAL, F. M. D.; RAMOS, C. A. C. Skeletal variability of Favia gravida (Verrill 1868) from Brazil. Biota Neotropica, São Paulo, v. 7, p. 1-7, 2007.

ANDRADE, G. O. O recife anular das Rocas (Um registro das recentes variações eustáticas no Atlântico equatorial). Anais da Associação dos Geógrafos Brasileiros, Porto Alegre, v. 11, p. 2961, 1959.

ARAÚJO, T. M. F. Morfologia, composição, sedimentologia e história evolutiva do recife de coral da Ilha de Itaparica, Bahia. 1984. 92 f. Dissertação (Mestrado em Geologia) - Universidade Federal da Bahia, Salvador. 1984.

CLOUD, P. E. Geology of Saipan, Mariana Islands. 4. Submarine topography and shoal-water ecology. US Geological Survey Professional Papers, Anchorage, v. 280, p. 361-445, 1959.

ECHEVERRÍA, C. A.; PIRES, D. O. Cnidarians of the Atol das Rocas. In: INTERNATIONAL CORAL REEF SYMPOSIUM, 8, 1997, Sidney. Proceedings..., Sidney: ICRS, 1997. p. 443-446.

EMILIANI, C. On the species Homotrema rubrum (Lamarck). Cushman Found Foraminifera Research Contribution, v. 2, p. 143-147, 1951.

GHERARDI, D. F. M.; BOSENCE, D. W. J. Modeling of the ecological succession of encrusting organisms in recent corallinealgal frameworks from Atol das Rocas, Brazil. Palaios, Lawrence, v. 14, n. 2, p. 145-158, 1999.

GHERARDI, D. F. M.; BOSENCE, D. W. J. Composition and community structure of the coralline algal reefs from Atol das Rocas, South Atlantic, Brazil. Coral Reefs, Heidelberg, v. 19, p. 205-19, 2001.

GISCHLER, E.; HUDSON, J. H. Holocene development of the Belize Barrier Reef. Sedimentary Geology, Fern Barrow, v. 164, p. 223-236, 2004

HETZEL, B.; CASTRO, C. B. Corais do Sul da Bahia. Rio de Janeiro: Nova Fronteira, 1994. 189 p.

HORTA, P. A. Bases para identificação das coralináceas não articuladas do litoral brasileiro - uma síntese do conhecimento. Biotemas, Florianópolis, v. 15, n. 1, p. 7-44, 2002.

KIKUCHI, R. K. P. Atol das Rocas, litoral do nordeste do Brasil - Único atol do Atlântico Sul Equatorial. In: SCHOBENHAUS, C.; CAMPOS, D. A.; QUEIROZ, E. T.; WINGE, M.; BERBETBORN, M. L. (Eds). Sítios geológicos e paleontológicos do Brasil. Brasília: DNPM/CPRM, 2002. p. 379-389.

KIKUCHI, R. K. P.; LEÃO, Z. M. A. N. Rocas (Southwestern Equatorial Atlantic, Brazil): an atoll built primarily by coralline algae. In: INTERNATIONAL CORAL REEF SYMPOSIUM, 8, 1997, Sidney. Proceedings..., Sidney: ICRS, 1997. p. 736.

LABOREL, J. Madréporaires et hydrocoralliaires recifaux des côtes brêsiliennes. Systematique, ecologie, repartition verticale et geographie. Annales Institut Oceanographie, Paris, v. 47, p. 171229,1969 a.
LABOREL, J. Les peuplements de madréporaries des côtes tropicales du Brêsil. Annales University d' Abidjan, Abidjan, v. 3, p. 1-261, 1969b.

LEÃO, Z. M. A. N. Guia para identificação dos corais do Brasil. Salvador: Editora da Universidade Federal da Bahia, 1986. 57 p.

LEÃO, Z. M. A. N.; ARAÚJO, T. M. F.; NOLASCO, M. C. The coral reefs off the coast of Eastern Brazil. In: INTERNATIONAL CORAL REEF SYMPOSIUM, 6, 1988, Cidade do Panamá. Proceedings... Cidade do Panamá: ICRS, 1988. Versão eletrônica.

LITTLER, M. M.; LITTLER, D. S. Caribean reef plant. An identification guide to the reef plants of the Caribbean, Bahamas, Florida and Gulf of Mexico. Washington: Off Shore Grafics Incorporate, 2000. $542 \mathrm{p}$.

LOEBLICH, A. R.; TAPPAN, H. Treatise on Invertebrate Paleontology. New York: Geological Society of America, 1964. $900 \mathrm{p}$.

LOEBLICH, A. R.; TAPPAN, H. Foraminiferal genera and their classification. New York: Geological Society of America, 1988. $970 \mathrm{p}$.

LOWENSTAM, H. A. Niagaran reefs of the Great Lakes area. The Journal of Geology, Chicago, v. 58, p. 430-487, 1950.

MACHADO, A. J.; SOUZA, F. B. C. Principais espécies de foraminíferos e briozoários do Atol das Rocas. Revista Brasileira de Geociências, Curitiba, v. 24, n. 4, p. 247-261, 1994.

MACINTYRE, S. Turbulent eddies and their implications for phytoplankton within the cuphotic zone of Lake Biwa, Japan. Japanese Journal of Limnology, Tokio, v. 57, p. 395-410, 1997.

MAIDA, M.; FERREIRA, B. P. Coral reefs of Brazil: an overview. In: INTERNATIONAL CORAL REEF SYMPOSIUM, 8, 1997, Sidney. Proceedings..., Sidney: ICRS, 1997. p. 263-274.

NAYLOR, L. A. The Contributions of biogeomorphology to emerging field of geobiology. Palaeogeography, Palaeoclimatology, Palaeoecology, New York, v. 219, p. 35-51, 2005.

NAYLOR, L. A.; VILES, H. A.; CARTER, N. E.A. Biogeomorphology revisited: looking towards the future Geomorphology, Charlottesville, v. 47, p. 3-14, 2002.

NEVES, E. G.; DA SILVEIRA, F. L. Release of planula larvae, settlement and development of Siderastrea stellata Verrill, 1868 (Anthozoa, Scleractinia). Hydrobiologia, Brussels, v. 501, p. 139147, 2003.

NEVES, E. G.; DA SILVEIRA, F. L.; PICHON, M.; JOHNSSON, R. Cnidaria, Scleractinia, Siderastreidae, Siderastrea siderea (Ellis and Solander, 1786): Hartt Expedition and the first record of a Caribbean siderastreid in tropical Southwestern Atlantic. Checklist, Rio Claro, v. 6, n. 4, p. 505-510, 2010.

NOLASCO, M. C. Construções carbonáticas da costa norte do Estado da Bahia (Salvador a Subaúma). 1987. 143 f. Dissertação (Mestrado em Geologia) - Universidade Federal da Bahia, Salvador. 1987.

OTTMAN, F. "L'atol das Rocas" dans l'Atlantique sud tropical. Revue de Géographie Physique et de Géologie Dinamique, Paris, v. 2, p. 101-107, 1963.

PENROSE, D.; WOELKERLING, W. J. A taxonomic reassessment of Hydrolithon Foslie, Porolithon Foslie and Pseudolithophyllum Lemoine (Corallinaceae, Rhodophyta) and their relationships to Spongites Kutzing. Phycologia, v. 27, p. 159-176, 1988. 
PEREIRA, N. S.; MANSO, V. A. V.; SILVA, A. M. C. Mapeamento geomorfológico e morfodinâmica do Atol das Rocas, Atlântico Sul. Revista da Gestão Costeira Integrada, Itajaí, v. 10, p. 331-345, 2010.

PERRIN, C. Ecological significance of paleocene to recent acervulinid foraminifera, their contribution to reef construction and other biogenic facies. Geobios, New York, v. 25, n. 6, p. 725-771, 1992.

PIRES, D. de O. Cnidoma da Ordem Scleractinia (Cnidaria, Anthozoa). 1995. 227 f. Tese (Doutorado em Zoologia) Universidade de São Paulo, São Paulo. 1995.

PIRES, D. de O. Cnidae of Scleractinia. Proceedings of the Biological Society of Washington, Washington, v. 110, n. 2, p. 167-185, 1997.

PIRES, D. de O.; CASTRO, C. B.; MIGOTTO, A. E.; MARQUES, A .C. Cnidários bentônicos do Arquipélago de Fernando de Noronha, Brasil. Boletim do Museu Nacional de Zoologia, Rio de Janeiro, v. 354, p. 1-21, 1992.

RIOS, E. de C. Seashells of Brazil. Rio Grande: Editora da Fundação Universidade do Rio Grande, 1994. 329 p.

ROSSI, A. R.; LEIPNITZ, I. I.; LEIPNITZ, B. Foraminíferos Holocênicos do Atol das Rocas. Acta Geologica Leopoldensia, São Leopoldo, v. 19, n. 4, p. 77-91, 1996.

SANTOS, M. G.; AMARAL, F. D.; HERNANDÉZ, M. I. M.; KNOWLTON, N.; JARÁ, J. Variação morfológica de Favia fravida Verrill, 1986 e Siderastrea stellata Verrill 1868 (Cnidaria, Scleractinia): aspectos esqueléticos. Boletim do Museu Nacional, Rio de Janeiro, v. 517, p.1- 9, 2004.
SMITH, F. G. W. Atlantic reef corals. Florida: University of Miami Press, 1971. 164 p.

SOARES, M. O.; LEMOS, V. B.; KIKUCHI, R. K. P. Atol das Rocas, Atlântico Sul Equatorial: considerações sobre a classificação do recife biogênico. Revista Brasileira de Geociências, Curitiba, v. 39, p. 238-243, 2009.

SOARES, M. O.; MEIRELlES, C. A. O.; LEMOS, V. B. Distribuição de vermetídeos incrustantes no Atol das Rocas, Atlântico Sul Equatorial. Boletim do Museu Paraense Emílio Goeldi. Série Ciências Naturais, Belém, v. 5, p. 225-231, 2010

STODDART, D. R. Ecology and morphology of recent coral reefs. Biological Reviews, Cambridge, v. 44, p. 433-498, 1969.

WOELKERLING, W. J. The coralline red algae: an analysis of the genera and subfamilies of nongeniculate Corallinaceae. Oxford: Oxford Press, 1988. 268 p.

WOELKERLING, W. J.; CAMPBELL, S. J. An account of southern Australia species of Lythophyllum (Corallinaceae, Rhodophyta). Bulletin of the British Museum (Natural History), Botany series, London, v. 22, p. 1-107, 1992.

WRAY, J. L. Development in Paleontology and Stratigraphy. Netherlands: Elsevier, 1977. 185 p. 